Old Labor and New Immigrants in American Political Development 

Old Labor and New Immigrants in American Political Development

\author{
Union, Party, and State, i875-I920
}

\title{
GWENDOLYN MINK
}

Cornell University Press ithaca and London 
Copyright $(\mathcal{C} 1986$ by Cornell University

All rights reserved. Except for brief quotations in a review, this book, or parts thereof, must not be reproduced in any form without permission in writing from the publisher. For information, address Cornell University Press, 124 Roberts Place, Ithaca, New York I4850.

First published I 986 by Cornell University Press.

International Standard Book Number 0-8014-I863-I

Library of Congress Catalog Card Number 85-30963

Printed in the United States of America

Librarians: Library of Congress cataloging information appears on last page of the book.

The paper in this book is acid-free and meets the guidelines for permanence and durability of the Committee on Production Guidelines for Book Longevity of the Council on Library Resources. 
For my grandmothers,

Mitama Tateyama Takemoto

and Helen Hlavaty Mink 


\section{Digitized by the Internet Archive in 2017 with funding from}

China-America Digital Academic Library (CADAL) 